\title{
Upon malpractice: The irremissible act of physicians
}

\author{
Malpraktis: Hekimlerin hoşgörülmez eylemi
}

\author{
Alparslan MERDiN, ${ }^{1}$ Fatma AVCI MERDiN² \\ ${ }^{1}$ Antalya Training and Research Hospital, Department of Internal Medicine, Antalya, Turkey \\ ${ }^{2}$ Akdeniz University Hospital, Department of Internal Medicine, Antalya, Turkey
}

\begin{abstract}
Medical malpractice can make harm to a patient directly or indirectly. The physician works on the patients. The physician's subject is human. An engineer can make a fault and can repair, but a physician should not. By the way, a physician is also a human and can make a fault. What should be the cost of this fault? There are more than one treatment ways, in some diseases such as in some cancer chemotherapies. Physicians must explain all the alternatives with all the complications, and must take consent forms.
\end{abstract}

Keywords: Medical malpractice; fine; medical harm; physician; cancer.
Tibbi malpraktis bir hastaya direkt veya indirekt yollarla zarar verebilir. Hekim hasta üzerinde çalışır. Hekiminlikte subjekt insandır. Bir mühendis bir hata yapabilir ve onarabilir, ancak bir doktor hata yapmamalıdır. Bunun yanında doktor da bir insandir ve bir hata yapabilir. Bu hatanın bedeli ne olmalıdır? Bazı kanser hastalarındaki kemoterapi tedavisi gibi, bazı hastalıklarda birden farklı tedavi yolları vardır. Doktorlar her zaman hastalarına tüm tedavi alternatiflerini ve tüm olası komplikasyonları ayrı ayrı açıklamalı ve hastalardan onam formları almalıdırlar.

Anahtar sözcükler: Tıbbi malpraktis; ceza; tıbbi zarar; doktor; kanser.
Medical malpractice can be in two ways. First way is giving harm to the patient by a physician during providing medical care to the patient. Second way is to provide less standart of medical care then a physician has to. Medical harms may be wrong body part operations, getting worse of the patients secondary to wrong treatments and death due to a wrong treatment. And here is an example of providing less standart of medical care.

An 36-year-old woman came to the emergency department. She intended to suicide. And she told about her suicide decision. She had also some pschyiatric problems. The woman was examined in the emergency service, prescribed a receipt; but was not hospitalized to the inpatient service. And that woman went to her house and killed herself with by shotting a gun. This is also medical practice. The physician did not directly harm the patient. But the physician did not do the standart responsibilities in a situation such as in this. And this caused a death.

The physician works on the patient. And a patient is human subject. An engineer can make a fault. For example, an engineer can make a wrong connection on the electronic system of a car. But engineer can change that failure, engineer can fix that. But we, the physicians, can not fix a death person. Any physician makes harm intentionally. Besides, we can not fix the harm we have made unintentionally to a human subject. All physicians do their best to help humans. On the other side, the cost of an unintentional failure may be terribly 
high. Do the physicians deserve that? Should the physicians live with the fear of malpractice? The fines of malpractice could be up to million dollars.

In conclusion, malpractice issue should be more discussed ethically and legally. Physicians should not do their jobs with the fear of malpractice.
Lastly, there are more than one treatment ways, in some diseases such as in some cancer chemotherapies. Physicians must explain to the patients all the alternative treatments with all the complications, and must take consent forms. And physicians must protect themselves from this irremissible act. 